\title{
PEMODELAN INDEKS HARGA SAHAM GABUNGAN (IHSG) DAN JAKARTA ISLAMIC INDEX (JII) MENGGUNAKAN REGRESI BIRESPON SPLINE TRUNCATED BERBASIS GUI R
}

\author{
Dhea Dewanti ${ }^{1}$, Suparti ${ }^{2}$, Alan Prahutama ${ }^{3}$ \\ ${ }^{1}$ Mahasiswa Departemen Statistika, FSM, Universitas Diponegoro \\ ${ }^{2,3}$ Staff Pengajar Departemen Statistika, FSM, Universitas Diponegoro \\ Email: dheadewanti29@gmail.com
}

\begin{abstract}
The capital market is one of the economic drivers and representations for assessing the condition of companies in a country. Indonesia Stock Exchange (IDX) as one of the institutions in the capital market has 24 types of indexes that can be used as main indicators that reflect the performance of capital market, two of them are the Composite Stock Price Index (CSPI) and the Jakarta Islamic Index (JII). CSPI and JII movements are influenced by several factors, both from domestic and from foreign, such as inflation and the Dow Jones Industrial Average (DJIA). Modeling of CSPI and JII in this study was carried out using birespon spline truncated nonparametric regression methods using Graphical User Interface (GUI) $\mathrm{R}$ with the intention of facilitating the analysis process. This method is used because there is a correlation between CSPI and JII and there is no specific relationship pattern between the response variable (CSPI and JII) and the predictor variable (inflation and DJIA). The best birespon spline truncated model is determined by the order, number and location of the knots seen based on minimum GCV criteria. By using monthly data from January 2016 to December 2019, the best birespon spline truncated model is obtained when the model for CSPI is in order 2 and the model for JII is in order 3 with 2 knots for each predictor variable. This model has a coefficient of determination of $85,54437 \%$ and MAPE of $2,65595 \%$ so that it has a very good ability in forecasting.
\end{abstract}

Keywords: CSPI, JII, Birespon Spline Truncated, GCV, GUI

\section{PENDAHULUAN}

Pasar modal merupakan salah satu penggerak perekonomian dan representasi untuk menilai kondisi perusahaanperusahaan di suatu negara. Bursa Efek Indonesia (BEI) sebagai salah satu lembaga di pasar modal saat ini memiliki 24 jenis indeks harga saham yang dapat digunakan sebagai indikator utama yang mencerminkan kinerja pasar modal. Dua diantaranya adalah Indeks Harga Saham Gabungan (IHSG) yang bersifat konvensional dan Jakarta Islamic Index (JII) yang bersifat syariah. Menurut [9], pergerakan indeks harga saham tersebut dipengaruhi oleh beberapa faktor baik dari dalam negeri (internal) maupun dari luar negeri (eksternal), seperti inflasi dan Dow Jones Industrial Average (DJIA).

Analisis faktor-faktor yang mempengaruhi pergerakan IHSG dan JII dapat dilakukan menggunakan regresi birespon dengan pendekatan nonparametrik. Analisis regresi birespon sendiri merupakan analisis regresi yang melibatkan dua variabel respon dan diantara kedua variabel tersebut terdapat korelasi atau hubungan yang kuat, baik secara logika maupun matematis [4]. Dalam regresi nonparametrik, bentuk kurva fungsinya tidak diketahui sehingga data akan mencari sendiri bentuk kurva regresinya [1]. Kurva regresi hanya diasumsikan smooth (mulus) termuat di dalam suatu ruang fungsi tertentu. Adapun 
salah satu metode regresi nonparametrik adalah spline. Spline merupakan potongan (piecewise) polinomial tersegmen (truncated) yang kontinu, sehingga memiliki kemampuan menyesuaikan diri lebih efektif terhadap pola data yang naik atau turun secara tajam dengan bantuan titik-titik knot [3].

$\mathrm{R}$ merupakan salah satu software statistika berbasis open source yang sudah banyak dikenal dan digunakan untuk keperluan pengembangan perangkat lunak statistik dan analisis data. Penggunaan $\mathrm{R}$ untuk metode regresi nonparametrik khususnya untuk regresi nonparametrik birespon spline truncated masih menggunakan CLI (Command Line Interface) dalam $\mathrm{R}$ console sehingga mengharuskan setiap pengguna untuk mengingat fungsi dan sintaks yang digunakan dalam analisis. Hal ini dirasa kurang efektif jika dalam penggunaannya terdapat banyak analisis statistika dan mengingat bahwa tidak semua pengguna mahir dalam menggunakan software $\mathrm{R}$ sehingga pengembangan GUI (Graphical User Interface) $\mathrm{R}$ diperlukan untuk memudahkan pengguna mengakses dan menganalisis data menggunakan software $\mathrm{R}$.

Berdasarkan permasalahan tersebut, penulis tertarik untuk mengembangkan GUI dengan software $\mathrm{R}$ untuk memodelkan data Indeks Harga Saham Gabungan (IHSG) dan Jakarta Islamic Index (JII) berdasarkan dua faktor yang mempengaruhinya, yaitu inflasi dan Dow Jones Industrial Average (DJIA) menggunakan metode regresi nonparametrik birespon spline truncated dengan pembobot invers matriks variansi kovariansi respon.

\section{Regresi Nonparametrik Birespon Spline Truncated}

Analisis regresi birespon merupakan analisis yang melibatkan dua variabel respon dan di antara variabel respon tersebut terdapat korelasi atau hubungan, baik secara logika maupun matematis [4]. Secara umum, model untuk regresi nonparametrik birespon spline truncated dengan dua variabel prediktor dapat dituliskan sebagai berikut:

$y_{i}^{(1)}=\beta_{0}^{(1)}+$

$\sum_{l=1}^{2} \sum_{k=1}^{m_{1}-1} \beta_{l, k}^{(1)} x_{i, l}^{k}+\sum_{l=1}^{2} \sum_{j=1}^{r} \beta_{l,\left(j+m_{1}-1\right)}^{(1)}\left(x_{i, l}-\right.$ $\left.K_{j, l}\right)_{+}^{m_{1}-1}+\varepsilon_{i}^{(1)}$

$y_{i}^{(2)}=\beta_{0}^{(2)}+$

$\sum_{l=1}^{2} \sum_{k=1}^{m_{2}-1} \beta_{l, k}^{(2)} x_{i, l}^{k}+\sum_{l=1}^{2} \sum_{j=1}^{r} \beta_{l,\left(j+m_{2}-1\right)}^{(2)}\left(x_{i, l}-\right.$ $\left.K_{j, l}\right)_{+}^{m_{2}-1}+\varepsilon_{i}^{(2)}$

[5] dengan $i=1,2,3, \ldots, n$

$m_{1} \quad$ : orde untuk respon 1

$m_{2} \quad$ : orde untuk respon 2

$r \quad$ : banyak knot yang digunakan

Bentuk Persamaan (1) dan (2) dapat ditulis ke dalam bentuk model matriks sebagai berikut.

$\mathbf{Y}=\mathbf{X} \boldsymbol{\beta}+\boldsymbol{\varepsilon}$

(3)

di mana

$\mathbf{Y}=\left[\begin{array}{l}y^{(1)} \\ -- \\ y^{(2)}\end{array}\right]_{[2 n \times 1]}$

dengan $\boldsymbol{y}^{(\mathbf{1})}=\left[\begin{array}{c}y_{1}^{(1)} \\ y_{2}^{(1)} \\ \vdots \\ y_{n}^{(1)}\end{array}\right]$ dan $\boldsymbol{y}^{(2)}=\left[\begin{array}{c}y_{1}^{(2)} \\ y_{2}^{(2)} \\ \vdots \\ y_{n}^{(2)}\end{array}\right]$

$X=\left[\begin{array}{c:c}A & B \\ - & - \\ C & D\end{array}\right]_{\left[2 n \times\left(2 \times\left(m_{1}+m_{2}+2 r\right)-2\right]\right.}$

Dengan

$$
\boldsymbol{A}=\left[\begin{array}{lll}
\boldsymbol{P} & \mid & \boldsymbol{Q}
\end{array}\right]
$$

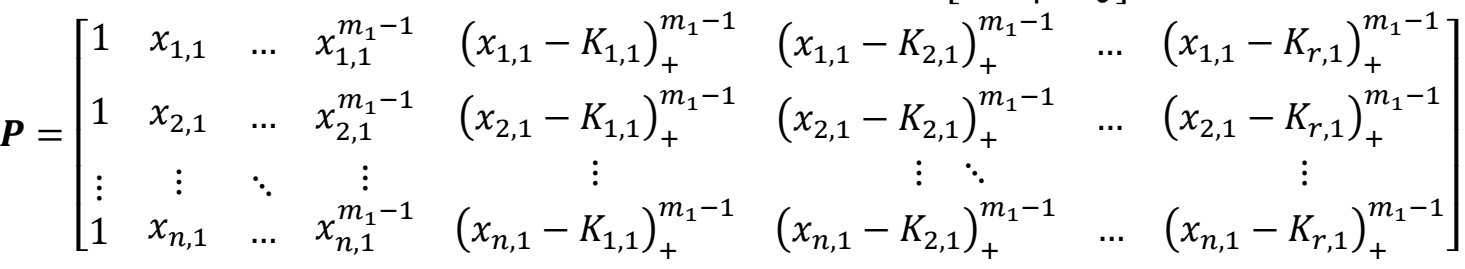




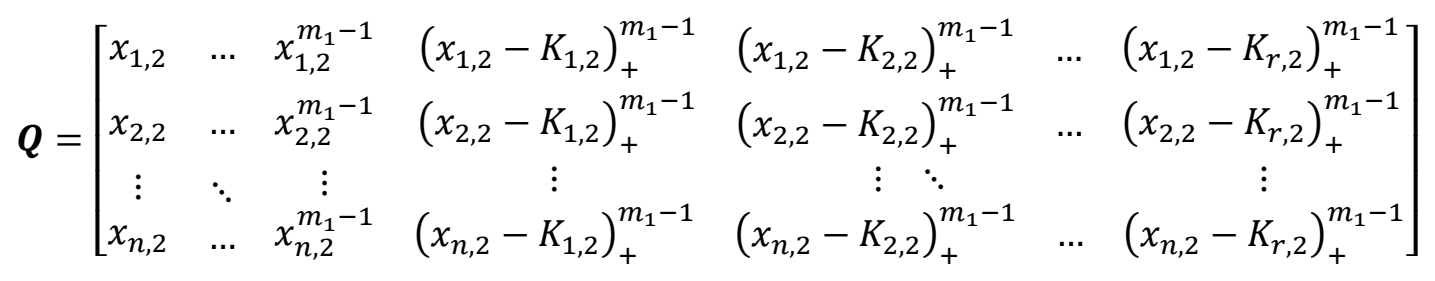$$
\boldsymbol{D}=\left[\begin{array}{lll}
\boldsymbol{R} & \mid & S
\end{array}\right]
$$

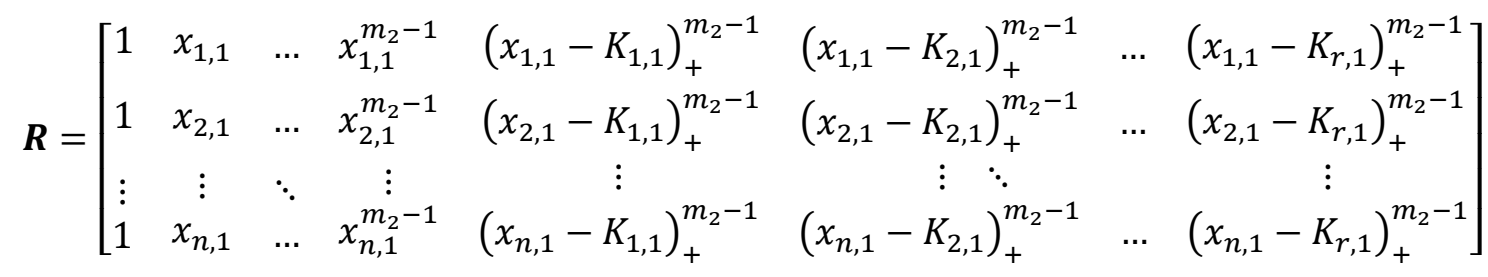$$
\boldsymbol{S}=\left[\begin{array}{ccccccc}
x_{1,2} & \ldots & x_{1,2}^{m_{2}-1} & \left(x_{1,2}-K_{1,2}\right)_{+}^{m_{2}-1} & \left(x_{1,2}-K_{2,2}\right)_{+}^{m_{2}-1} & \ldots & \left(x_{1,2}-K_{r, 2}\right)_{+}^{m_{2}-1} \\
x_{2,2} & \ldots & x_{2,2}^{m_{2}-1} & \left(x_{2,2}-K_{1,2}\right)_{+}^{m_{2}-1} & \left(x_{2,2}-K_{2,2}\right)_{+}^{m_{2}-1} & \ldots & \left(x_{2,2}-K_{r, 2}\right)_{+}^{m_{2}-1} \\
\vdots & \ddots & \vdots & \vdots & \vdots & \ddots & \\
x_{n, 2} & \ldots & x_{n, 2}^{m_{2}-1} & \left(x_{n, 2}-K_{1,2}\right)_{+}^{m_{2}-1} & \left(x_{n, 2}-K_{2,2}\right)_{+}^{m_{2}-1} & \ldots & \left(x_{n, 2}-K_{r, 2}\right)_{+}^{m_{2}-1}
\end{array}\right]
$$

$$
\boldsymbol{\beta}=\left[\begin{array}{c}
\boldsymbol{\beta}^{(\mathbf{1})} \\
-- \\
\boldsymbol{\beta}^{(2)}
\end{array}\right]_{\left[\left(2 \times\left(\boldsymbol{m}_{\mathbf{1}}+\boldsymbol{m}_{\mathbf{2}}+\mathbf{2 r}\right)-\mathbf{2}\right) \times \mathbf{1}\right]} \operatorname{dengan} \boldsymbol{\beta}^{(\mathbf{1})}=\left[\begin{array}{c}
\beta_{0}^{(1)} \\
\beta_{1,1}^{(1)} \\
\beta_{1,2}^{(1)} \\
\vdots \\
\beta_{1,\left(r+m_{1}-1\right)}^{(1)} \\
\beta_{2,1}^{(1)} \\
\beta_{2,2}^{(1)} \\
\vdots \\
\beta_{2,\left(r+m_{1}-1\right)}^{(1)}
\end{array}\right] \operatorname{dan} \boldsymbol{\beta}^{(2)}=\left[\begin{array}{c}
\beta_{0}^{(2)} \\
\beta_{1,1}^{(2)} \\
\beta_{1,2}^{(2)} \\
\vdots \\
\beta_{1,\left(r+m_{2}-1\right)}^{(2)} \\
\beta_{2,1}^{(2)} \\
\beta_{2,2}^{(2)} \\
\vdots \\
\beta_{2,\left(r+m_{2}-1\right)}^{(2)}
\end{array}\right]
$$$$
\boldsymbol{\varepsilon}=\left[\begin{array}{c}
\boldsymbol{\varepsilon}^{(\mathbf{1})} \\
-- \\
\boldsymbol{\varepsilon}^{(2)}
\end{array}\right]_{[2 \boldsymbol{n} \times \mathbf{1}]} \text { dengan } \boldsymbol{\varepsilon}^{(\mathbf{1})}=\left[\begin{array}{c}
\varepsilon_{1}^{(1)} \\
\varepsilon_{2}^{(1)} \\
\vdots \\
\varepsilon_{n}^{(1)}
\end{array}\right] \text { dan } \boldsymbol{\varepsilon}^{(2)}=\left[\begin{array}{c}
\varepsilon_{1}^{(2)} \\
\varepsilon_{2}^{(2)} \\
\vdots \\
\varepsilon_{n}^{(2)}
\end{array}\right]
$$

Matriks $\boldsymbol{A}$ adalah matriks berukuran $n \times$ $\left(2 \times\left(m_{1}+r\right)-1\right)$ dan $\boldsymbol{D}$ adalah matriks berukuran $n \times\left(2 \times\left(m_{2}+r\right)-1\right)$. Sedangkan $\boldsymbol{B}$ adalah matriks berukuran $n \times\left(2 \times\left(m_{2}+r\right)-1\right) \quad$ yang semua elemennya bernilai nol (0) dan $\boldsymbol{C}$ adalah matriks berukuran $n \times\left(2 \times\left(m_{1}+r\right)-1\right)$ yang semua elemennya bernilai nol (0).

\section{Estimasi Parameter Weighted Least Square (WLS)}

Dalam kasus pemodelan regresi dengan respon lebih dari satu, diperlukan matriks pembobot $\mathbf{W}$ yang melibatkan nilai korelasi dan kovariansi. Menurut [15], matriks pembobot yang melibatkan nilai korelasi dan kovariansi adalah $\boldsymbol{W}=\boldsymbol{V}^{\mathbf{- 1}}$, di mana $\boldsymbol{V}$ merupakan matriks kovariansi dari variabel respon dengan ukuran $2 n \times 2 n$. 
Pendugaan terhadap vektor parameter $\boldsymbol{\beta}$ pada persamaan (3) dilakukan dengan menggunakan metode WLS dengan meminimumkan Jumlah Kuadrat Error Terboboti. Berdasarkan estimasi $\widehat{\boldsymbol{\beta}}$ menggunakan metode WLS, diperoleh persamaan regresi nonparametrik birespon spline truncated sebagai berikut:

$\widehat{\boldsymbol{Y}}=\boldsymbol{X} \widehat{\boldsymbol{\beta}}$

$\widehat{Y}=X\left(X^{T} W X\right)^{-1} X^{T} W Y$

\section{Pemilihan Titik Knot Optimal}

Titik knot merupakan titik perpaduan bersama yang memperlihatkan terjadinya perubahan perilaku fungsi spline pada interval-interval yang berbeda [1]. Untuk mendapatkan spline optimal perlu dipilih banyaknya titik knot yang optimal. Salah satu metode yang paling banyak dipakai dan disukai karena kelebihan yang dimilikinya adalah metode GCV (Generalized Cross Validation). Dibandingkan metode lain, misal Cross Validation (CV), metode GCV mempunyai sifat optimal asimtotik [13]. Adapun rumus GCV secara umum didefinisikan sebagai berikut.

$G C V=\frac{M S E}{\left(N^{-1} \operatorname{tr}[I-H]\right)^{2}}$

dengan $\boldsymbol{H}=\boldsymbol{X}\left(\boldsymbol{X}^{\boldsymbol{T}} \boldsymbol{W} \boldsymbol{X}\right)^{-\mathbf{1}} \boldsymbol{X}^{\boldsymbol{T}} \boldsymbol{W}$ dan $N=$ $2 n$.

\section{Uji Korelasi Pearson}

Analisis korelasi adalah metode statistik yang digunakan untuk mengukur besarnya hubungan linier antara dua variabel dengan satu nilai yang dinamakan koefisien korelasi [14]. Pengujian koefisien korelasi dapat dilakukan dengan menggunakan uji hipotesis sebagai berikut:

- Hipotesis

$\mathrm{H}_{0}: \rho=0$ (tidak terdapat korelasi linier di antara kedua variabel)

$\mathrm{H}_{1}: \rho \neq 0$ (terdapat korelasi linier di antara kedua variabel)

- Statistik Uji

$t=\frac{r \sqrt{n-2}}{\sqrt{1-r^{2}}}$

dengan $n$ merupakan banyaknya pasangan data dari variabel-variabel yang diduga berkorelasi dan $r$ merupakan nilai koefisien korelasi yang diperoleh berdasarkan persamaan berikut.

$$
r=\frac{\sum_{i=1}^{n}\left(X_{i}-\bar{X}\right)\left(Y_{i}-\bar{Y}\right)}{\sqrt{\left(\sum_{i=1}^{n}\left(X_{i}-\bar{X}\right)^{2}\right)\left(\sum_{i=1}^{n}\left(Y_{i}-\bar{Y}\right)^{2}\right)}}
$$

- Kriteria Uji

$\mathrm{H}_{0}$ ditolak jika nilai $\left|t_{\text {hitung }}\right|>t_{\frac{\alpha}{2}, n-2}$

Jika $\mathrm{H}_{0}$ ditolak, maka terdapat korelasi linier di antara kedua variabel.

\section{Koefisien Determinasi $\left(\mathbf{R}^{\mathbf{2}}\right)$}

Koefisien determinasi digunakan untuk menunjukkan seberapa besar persentase keragaman dalam variabel respon yang dijelaskan oleh variabel prediktor. Nilai dari $R^{2}$ adalah $0 \leq R^{2} \leq 1$, jika $R^{2}$ bernilai 1 berarti terjadi suatu kecocokan sempurna, sedangkan jika $R^{2}$ bernilai 0 berarti tidak ada hubungan antara variabel prediktor dengan variabel respon [6]. Koefisien determinasi untuk regresi birespon dapat dihitung dengan rumus sebagai berikut.

$R^{2}=\frac{\sum_{j=1}^{2} \sum_{i=1}^{n}\left(\left(\hat{y}_{i}^{(j)}-\bar{y}^{(j)}\right)\right)^{2}}{\sum_{j=1}^{2} \sum_{i=1}^{n}\left(\left(y_{i}^{(j)}-\bar{y}^{(j)}\right)\right)^{2}}$

\section{Mean Absolute Percentage Error (MAPE)}

Evaluasi hasil peramalan digunakan untuk mengetahui ketepatan hasil peramalan yang telah dilakukan terhadap data yang sebenarnya. Rumus untuk menghitung MAPE dari regresi birespon adalah sebagai berikut.

$M A P E=\frac{1}{N} \sum_{j=1}^{2} \sum_{i=1}^{n}\left|\frac{y_{i}^{(j)}-\hat{y}_{i}^{(j)}}{y_{i}^{(j)}}\right| \times 100 \%$

\section{Graphical User Interface R (GUI-R)}

$\mathrm{R}$ adalah suatu bahasa pemrograman yang handal dan lingkungan perangkat lunak untuk komputasi statistik dan grafis. Pada dasarnya $\mathrm{R}$ berinteraksi secara CLI (Command Line Interface) yaitu dengan membaca perintah yang dikirim melalui Jendela R-Console. Untuk membantu pengguna yang biasa bekerja dengan GUI (Graphical User Interface), berbagai macam menu telah dikembangkan oleh berbagai kelompok. Menurut [11], salah 
satu package $\mathrm{R}$ yang dapat digunakan untuk membangun GUI adalah Shiny. Shiny merupakan interface yang memungkinkan pengguna membuat laman web (web pages) interaktif sehingga kemampuan $\mathrm{R}$ yang pada dasarnya bersifat CLI bisa diakses melalui menu web secara GUI web.

\section{METODE PENELITIAN}

\section{Sumber Data dan Variabel Penelitian}

Data yang digunakan dalam penelitian ini merupakan data sekunder, yaitu data Indeks Harga Saham Gabungan (IHSG), Jakarta Islamic Index (JII) dan Dow Jones Industrial Average (DJIA) yang diperoleh dari situs yahoo finance (https://finance.yahoo.com) serta data inflasi yang diperoleh dari Website Bank Indonesia (https://www.bi.go.id). Data dalam penelitian ini dibagi menjadi dua, yaitu data in sample yang digunakan dalam pembentukan model dengan periode data bulanan terhitung sejak Januari 2016 sampai dengan Desember 2018 dan data out sample yang digunakan untuk peramalan dengan periode data bulanan terhitung sejak Januari 2019 sampai dengan Desember 2019.

Variabel yang digunakan dalam penelitian ini terdiri dari dua variabel respon dan dua variabel prediktor, yaitu IHSG sebagai variabel respon pertama, JII sebagai variabel respon kedua, inflasi sebagai variabel prediktor pertama dan DJIA sebagai variabel prediktor kedua.

\section{Metode Analisis}

Adapun langkah-langkah dalam pelaksanaan peneltian dan analisis data yaitu diawali dengan menentukan data yang akan digunakan, dilanjutkan dengan mengidentifikasi metode analisis yang akan digunakan, yaitu analisis regresi nonparametrik birespon spline truncated dengan pembobot invers matriks variansi kovariansi respon. Langkah selanjutnya yaitu mengidentifikasi hal-hal yang dibutuhkan dalam pembuatan GUI termasuk di dalamnya proses kerja GUI saat dijalankan. Kemudian membuat GUI dengan menggunakan software $\mathrm{R}$ dan melakukan analisis regresi nonparametrik birespon spline truncated menggunakan GUI yang telah dibuat.

\section{HASIL DAN PEMBAHASAN}

\section{Deskripsi Data}

Data yang digunakan dalam penelitian ini merupakan data sekunder, yaitu data closing price Indeks Harga Saham Gabungan (IHSG) sebagai variabel respon pertama $\left(\mathrm{y}^{(1)}\right)$ dan data closing price Jakarta Islamic Index (JII) sebagai variabel respon kedua $\left(\mathrm{y}^{(2)}\right)$. Sedangkan variabel prediktor yang digunakan adalah data inflasi sebagai variabel prediktor pertama $\left(\mathrm{x}_{1}\right)$ dan data closing price Dow Jones Industrial Average (DJIA) sebagai variabel prediktor kedua $\left(\mathrm{x}_{2}\right)$. Dalam penelitian ini, data dibagi menjadi dua yaitu data in sample yang digunakan untuk membentuk model dan data out sample yang digunakan untuk mengevaluasi model yang diperoleh. Statistik deskriptif dari data in sample setiap variabel penelitian dapat dilihat dalam Tabel 1 berikut.

Tabel 1. Statistik Deskriptif Data

\begin{tabular}{|c|c|c|c|c|}
\hline Variabel & $\mathbf{N}$ & Minimum & Maksimum & Rata-Rata \\
\hline $\mathrm{y}^{(1)}$ & 36 & $4.615,00$ & $6.606,00$ & $5.648,00$ \\
\hline $\mathrm{y}^{(2)}$ & 36 & 612,80 & 787,10 & 701,60 \\
\hline $\mathrm{x}_{1}$ & 36 & 2,79 & 4,45 & 3,51 \\
\hline $\mathrm{x}_{2}$ & 36 & $16.466,00$ & $26.458,00$ & $21.654,00$ \\
\hline $\begin{array}{l}\text { Anal } \\
\text { Trun }\end{array}$ & & Regresi & Birespon & Spline \\
\hline
\end{tabular}

Sebelum dilakukan analisis regresi birespon spline truncated, akan dilakukan uji korelasi menggunakan metode Pearson untuk mengetahui ada tidaknya hubungan antara IHSG sebagai variabel respon pertama $\left(\mathrm{y}^{(1)}\right)$ dan JII sebagai variabel respon kedua $\left(\mathrm{y}^{(2)}\right)$. Apabila diantara kedua variabel respon tersebut tidak terdapat hubungan atau korelasi linier, maka analisis regresi birespon tidak dapat dilakukan. Berdasarkan perhitungan dengan software $\mathrm{R}$, diperoleh nilai koefisien korelasi antara IHSG dan JII sebesar 0,511 dengan $t_{\text {hitung }}$ sebesar 3,4693 dan p-value sebesar 0,001437 . Hal ini berarti bahwa pada taraf 
signifikansi $\alpha=5 \%$ terdapat korelasi linier antara variabel respon IHSG dan variabel respon JII sehingga analisis dapat dilanjutkan menggunakan analisis regresi birespon. Tahap selanjutnya adalah membuat scatterplot antara variabel respon dan variabel prediktor. Jika kurva regresi antara variabel respon dan variabel prediktor tidak membentuk suatu pola tertentu, maka pendekatan dapat menggunakan pendekatan nonparametrik.

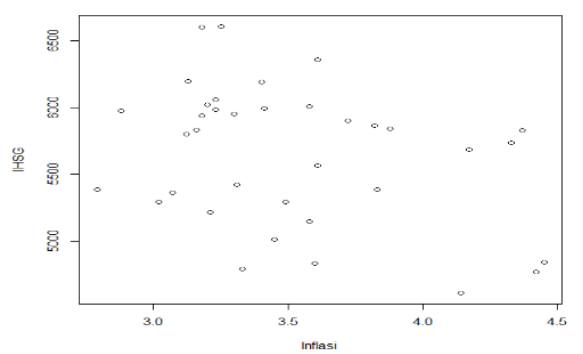

Gambar 1. Scatterplot antara IHSG dan Inflasi

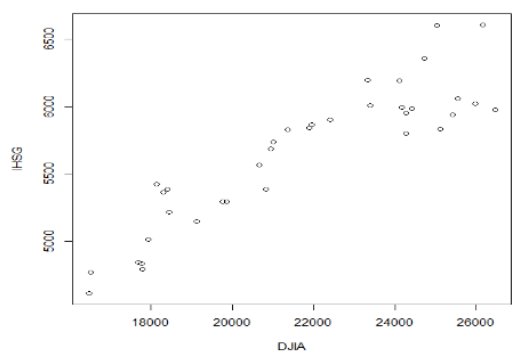

Gambar 2. Scatterplot antara IHSG dan DJIA

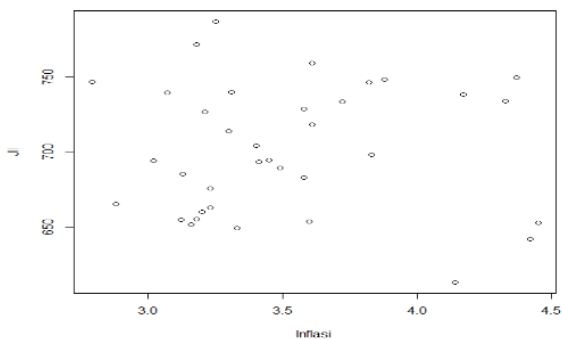

Gambar 3. Scatterplot antara JII dan Inflasi

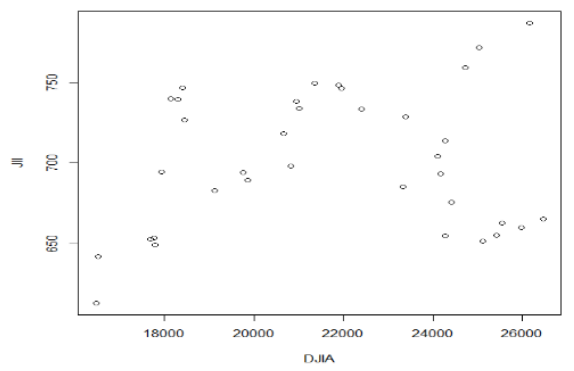

Gambar 4. Scatterplot antara JII dan DJIA
Berdasarkan scatterplot pada Gambar 1, Gambar 2, Gambar 3 dan Gambar 4 terlihat bahwa keempat plot antara variabel respon IHSG dan JII dengan masing-masing variabel prediktornya yaitu inflasi dan DJIA mengalami kenaikan dan penurunan. Keempat plot tersebut menunjukkan bahwa tidak terdapat kecenderungan pola hubungan tertentu sehingga tidak diketahui bentuk kurva regresinya. Oleh karena itu, pemodelan regresi pada penelitian akan dilakukan menggunakan pendekatan nonparametrik birespon spline truncated.

Dalam model birespon spline truncated, performa model sangat ditentukan oleh orde, banyaknya titik knot dan letak titik knot. Model yang optimal diperoleh dengan melakukan kombinasi orde antara variabel prediktor pada model respon $\mathrm{y}^{(1)}$ dan model respon $\mathrm{y}^{(2)}$, menentukan banyaknya titik knot dan letak titik knot pada variabel prediktor. Pada penelitian ini, pemilihan kombinasi orde dan titik knot optimal dilakukan menggunakan metode GCV (Generalized Cross Validation). Kombinasi orde dan titik knot optimal diperoleh dari model yang memiliki nilai GCV minimum. Banyaknya orde yang dicobakan pada variabel prediktor setiap variabel respon adalah 2, 3 dan 4 dengan banyak titik knot yang akan digunakan pada kedua variabel prediktor selalu sama, yaitu satu sampai empat titik knot. Berikut disajikan model terbaik berdasarkan kriteria GCV minimum untuk setiap banyaknya titik knot yang dicobakan. 
Tabel 2. Nilai GCV Minimum pada masing-masing jumlah knot

\begin{tabular}{ccccccccccc}
\hline \multirow{2}{*}{$\begin{array}{c}\text { Orde } \\
\mathrm{y}^{(1)}\end{array}$} & $\begin{array}{c}\text { Orde } \\
\mathrm{y}^{(2)}\end{array}$ & GCV & \multicolumn{4}{c}{ Titik Knot $\mathrm{x}_{1}$} \\
\cline { 5 - 11 } & Minimum & $\mathrm{K}_{1,1}$ & $\mathrm{~K}_{2,1}$ & $\mathrm{~K}_{3,1}$ & $\mathrm{~K}_{4,1}$ & $\mathrm{~K}_{1,2}$ & $\mathrm{~K}_{2,2}$ & $\mathrm{~K}_{3,2}$ & $\mathrm{~K}_{4,2}$ \\
\hline 3 & 3 & $24.996,31$ & 2,88 & - & - & - & $16.516,50$ & - & - & - \\
2 & 3 & $10.524,50$ & 3,31 & 3,60 & - & - & $19.762,60$ & $20.940,51$ & - & - \\
3 & 4 & $20.056,44$ & 3,33 & 4,14 & 4,17 & - & $18.432,24$ & $20.812,24$ & $25.415,19$ & - \\
2 & 3 & $14.547,92$ & 3,40 & 3,61 & 3,83 & 4,17 & $18.308,15$ & $18.400,88$ & $19.123,58$ & $23.377,24$ \\
\hline
\end{tabular}

Berdasarkan Tabel 2, diperoleh model birespon spline kombinasi orde dan titik knot terbaik dari semua kombinasi yang dicobakan adalah model birespon spline pada saat $\mathrm{y}^{(1)}$ berorde 2 dan $\mathrm{y}^{(2)}$ berorde 3 dengan titik knot optimal untuk $\mathrm{x}_{1}$ pada titik 3,31 dan 3,6 dan titik knot optimal untuk $\mathrm{x}_{2}$ pada titik 19.762,60 dan 20.940,51. Sehingga diperoleh model terbaik birespon spline truncated untuk variabel respon IHSG $\left(\mathrm{y}^{(1)}\right)$ sebagai berikut:

$$
\begin{aligned}
\hat{y}_{i}^{(1)}=881,8149 & +0,237241 x_{i, 1} \\
& -3,77534\left(x_{i, 1}-3,31\right)_{+} \\
& -11,6002\left(x_{i, 1}-3,6\right)_{+} \\
& +0,23146 x_{i, 2} \\
& -0,02894\left(x_{i, 2}-19762,6\right)_{+} \\
& -0,10018\left(x_{i, 2}-20940,51\right)_{+}
\end{aligned}
$$

Sedangkan model terbaik birespon spline truncated untuk variabel respon JII $\left(\mathrm{y}^{(2)}\right)$ diperoleh model sebagai berikut:

$$
\begin{array}{rl}
\hat{y}_{i}^{(2)}=-4181,8 & 11-726,8591 x_{i, 1} \\
& +113,5448 x_{i, 1}{ }^{2} \\
& +15,3325\left(x_{i, 1}-3,31\right)_{+}{ }^{2} \\
& -238,8315\left(x_{i, 1}-3,6\right)_{+}{ }^{2} \\
& +0,6302791 x_{i, 2} \\
& -\left(1,640652 \times 10^{-5}\right) x_{i, 2}{ }^{2} \\
& +(2,539471 \\
& \left.\times 10^{-5}\right)\left(x_{i, 2}-19762,6\right)_{+}{ }_{+} \\
& -(9,67307 \\
& \left.\times 10^{-6}\right)\left(x_{i, 2}-20940,51\right)_{+}{ }_{+}
\end{array}
$$

Model tersebut memiliki nilai GCV sebesar 10.524,5 dan $\mathrm{R}^{2}$ sebesar 85,54437\%. Berikut plot antara data aktual dan hasil prediksi.

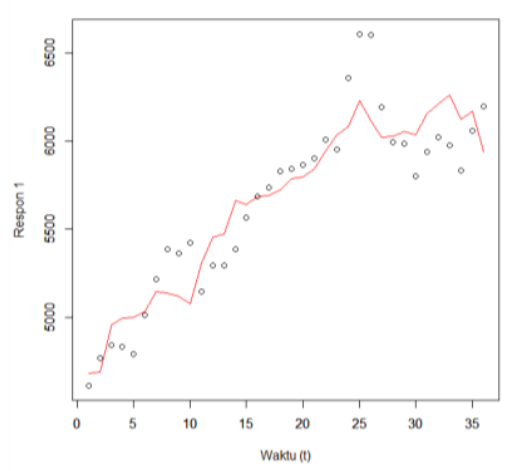

Gambar 5. Scatterplot antara Data Aktual dan Hasil Prediksi Respon 1

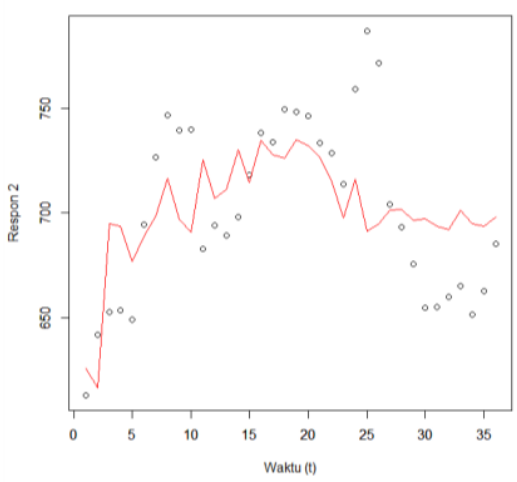

Gambar 6. Scatterplot antara Data Aktual dan Hasil Prediksi Respon 2

Dari model terbaik yang diperoleh, selanjutnya dilakukan peramalan untuk data out sample dan diperoleh MAPE sebesar 2,65595 \% yang menunjukkan persentase kesalahan prediksi yang dihasilkan oleh model. Nilai MAPE yang kurang dari $10 \%$ berarti bahwa model birespon spline truncated terbaik yang diperoleh mempunyai kemampuan yang sangat baik jika digunakan untuk peramalan.

\section{Persiapan Kebutuhan dalam Pembuatan GUI}

Sebelum membuat GUI, persiapan yang harus dilakukan adalah mengidentifikasi komponen-komponen 
yang dibutuhkan dalam pembuatan GUI. Komponen-komponen tersebut meliputi input, proses dan output. Untuk bagian input, diperlukan file data yang akan digunakan untuk analisis regresi birespon spline truncated. File tersebut harus disimpan dalam bentuk *.csv atau *.txt. Kemudian untuk bagian proses dan output sepenuhnya menggunakan software R i386 3.6.0 dan RStudio. Pembuatan program GUI menggunakan software $\mathrm{R}$ ini dilakukan dengan bantuan paket shiny sebagai paket utama untuk pembuatan GUI serta paket ggplot2, ggthemes, gridExtra dan scatterplot $3 d$ sebagai paket pendukung untuk membuat plot data.

\section{Pendesainan Tampilan Antarmuka (User Interface) dalam GUI}

Setelah semua komponen yang diperlukan dalam pembuatan GUI tersedia, tahap selanjutnya adalah mendesain tampilan antarmuka dalam GUI. Pada paket shiny, tampilan antarmuka didefinisikan menggunakan objek bernama ui yang disimpan dalam file app.R. Pada bagian ini akan diatur bagaimana tampilan dari panel kontrol, input yang diperlukan serta output yang akan ditampilkan. Berikut tampilan GUI saat pertama kali dijalankan.

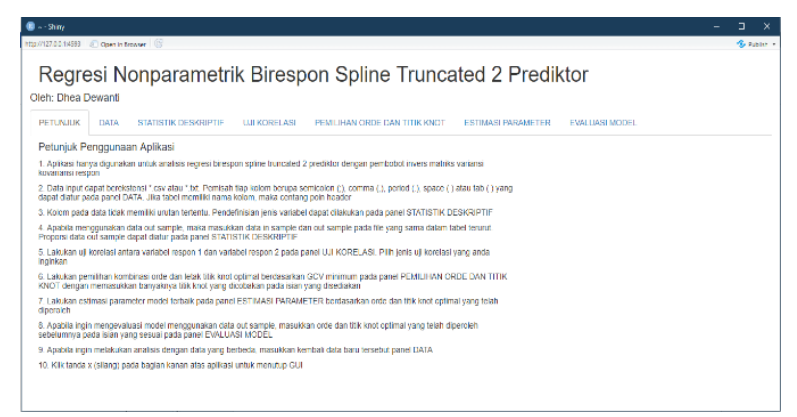

Gambar 7. Tampilan Antarmuka GUI

\section{Penyusunan Perintah (Server) dalam GUI}

Pada tahapan pembuatan GUI, setelah mendesain tampilan antarmuka maka tahapan selanjutnya adalah menyusun sintaks pada fungsi server. Fungsi ini memuat semua proses yang dijalankan dalam GUI. Dalam pembuatan program analisis regresi birespon spline truncated, diperlukan beberapa paket bawaan dari RStudio yang berkaitan langsung dengan pengolahan data. Adapun paket yang digunakan adalah ggplot2, ggthemes, gridExtra dan scatterplot3d. Keempat paket ini digunakan untuk membuat time series plot, scatterplot dan 3D plot pada GUI. Semua paket yang diinstall secara online saat software Rstudio dijalankan secara otomatis akan mengunduh paket lainnya yang berhubungan dengan paket tersebut. Selain menggunakan paket bawaan dari Rstudio, proses pengolahan data pada GUI juga membutuhkan lima sintaks utama yang disimpan dalam file $\mathrm{R}$.

\section{Penyatuan User Interface dan Server dalam GUI}

Tahapan selanjutnya setelah pembuatan obyek ui dan fungsi server selesai adalah menyatukan kedua komponen tersebut dalam file app.R. File app.R tersebut tidak hanya berisi obyek ui dan fungsi server, tetapi juga berisikan library serta source fungsi buatan yang digunakan dalam proses pembuatan dan pengolahan GUI. Semua file fungsi buatan tersebut harus disimpan dalam folder yang sama dengan file app.R. Untuk menampilkan antarmuka GUI, digunakan fungsi

shinyApp (ui=ui, server=server

). Jika tidak terdapat error pada salah satu file $\mathrm{R}$ yang digunakan, maka jendela utama GUI akan muncul seperti pada Gambar 8. Berikut format sintaks pada file app.R yang digunakan dalam pembuatan GUI "Regresi Birespon Spline Truncated 2 Prediktor".

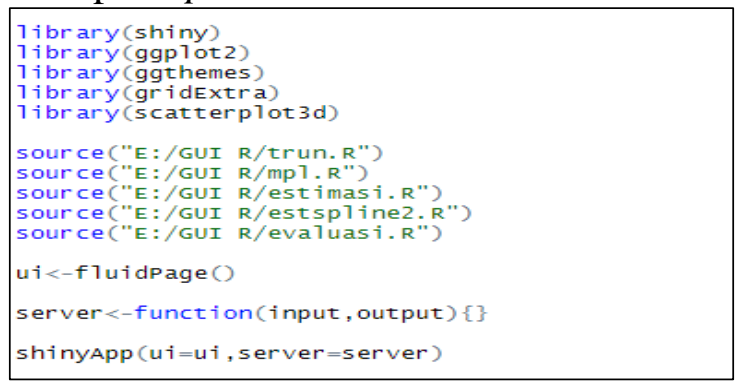

Gambar 8. Format Sintaks pada File app.R 


\section{Penggunaan dan Hasil dari GUI}

Berdasarkan analisis regresi birespon spline truncated yang dilakukan sebelumnya, Gambar 9 merupakan output

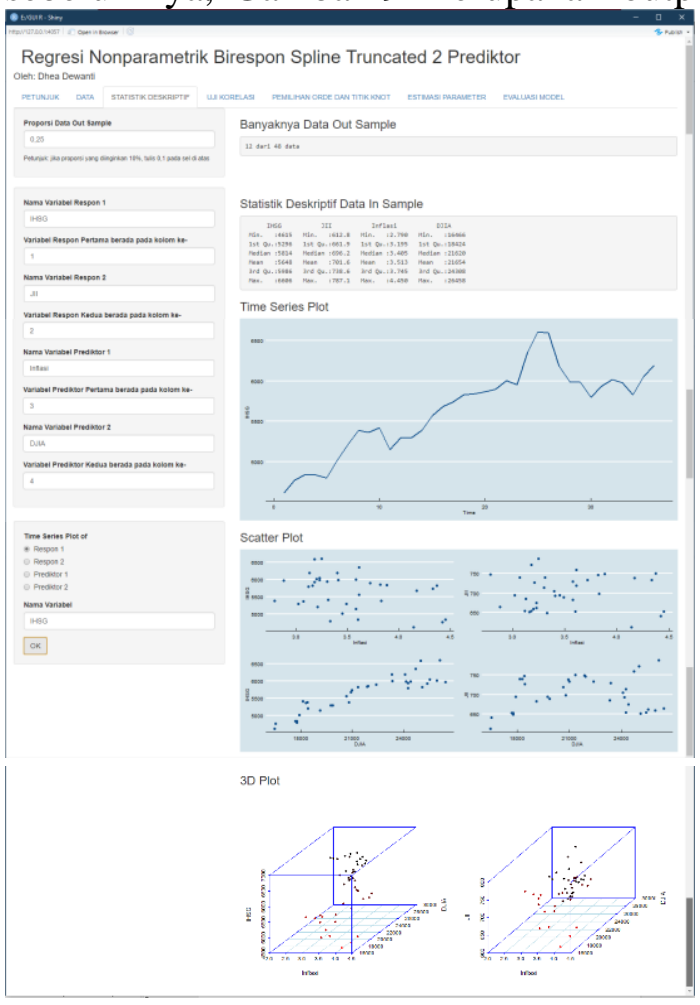

Regresi Nonparametrik Birespon Spline Truncated 2 Prediktor

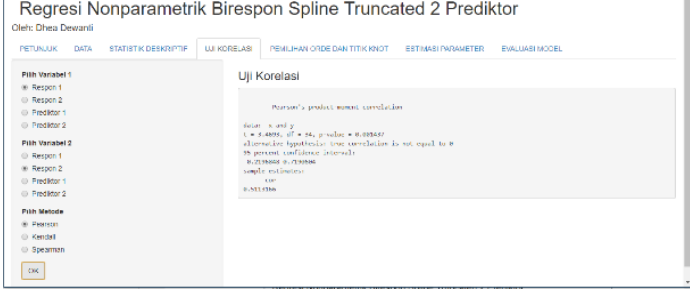

yang ditunjukkan GUI dan memberikan hasil yang sama dengan analisis pada bagian sebelumnya

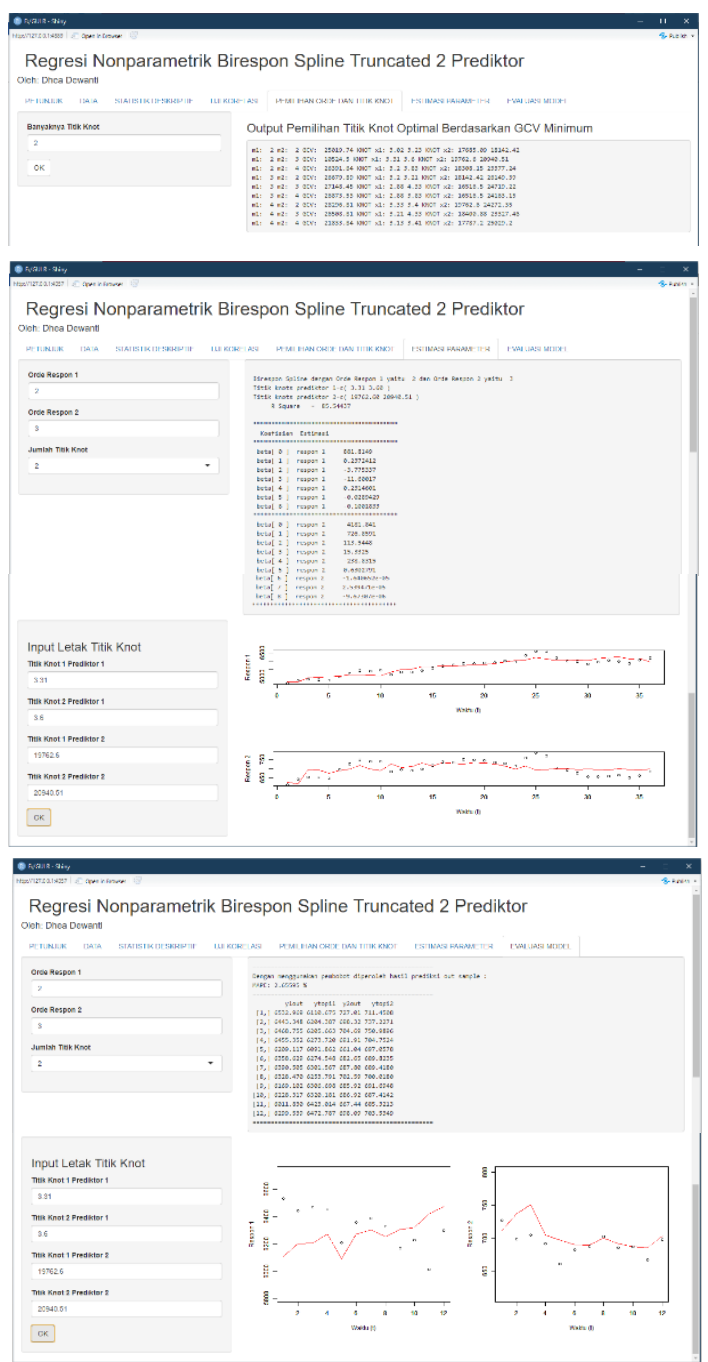

Gambar 9. Tampilan GUI R Setelah Dilakukan Impor Data

\section{KESIMPULAN}

Dengan menggunakan data bulanan pada tahun 2016 - 2019, diperoleh model birespon spline truncated terbaik untuk memodelkan data Indeks Harga Saham Gabungan dan Jakarta Islamic Index pada saat model untuk IHSG berorde 2 dan untuk JII berorde 3 dengan titik knot optimal untuk inflasi pada titik 3,31 dan 3,6 dan titik knot optimal untuk Dow Jones Industrial Average pada titik 19.762,6 dan 20.940,51. Model terbaik tersebut memiliki $\mathrm{R}^{2}$ sebesar 85,54437\% dan MAPE out sample sebesar $2,65595 \%$. Hal ini juga ditunjukkan dari
GUI yang telah dibuat dan menampilkan output yang sesuai dari hasil penggunaannya. GUI tersebut memudahkan pengguna untuk menganalisis data menggunakan regresi nonparametrik birespon spline truncated walaupun masih memiliki keterbatasan dalam beberapa bagian

\section{DAFTAR PUSTAKA}

[1] Budiantara, I.N. 2005. Model Keluarga Spline Polinomial Truncated dalam Regresi Semiparametrik. BIMIPA Vol. 15, No. 3: Hal. 55-61. 
[2] Chen, R. J. C., Bloomfield, P., \& Cubbage, F. W. 2008. Comparing Forecasting Models in Tourism. Journal of Hospitality \& Tourism Research Vol. 32, No. 1: Hal. 3-21.

[3] Eubank, R.L. 1999. Nonparametric Regression and Spline Smoothing. Second Edition. New York: Marcel Dekker, Inc.

[4] Fernandes, A.A.R., Budiantara, I.N., Otok, B.W., and Suhartono. 2014. Spline Estimator for Bi-responses Nonparametric Regression Model for Longitudinal Data. Applied Mathematical Sciences Vol. 8, No. 114: Hal. 5653-5665.

[5] Fernandes, A.A.R. 2016. Truncated Spline for Estimating the Curve of Nonparametric Regressions Biresponsesfor Prediction the Inflation and Economic Growth in Malang, Indonesia, Year 2001-2015. International Journal of Social Relevance \& Concern ISSN-23479698 Vol 4: Hal. 26-32.

[6] Gujarati, D.N. 2003. Basic Econometrics. Fourth Edition. New York: MCGraw-Hill Companies, Inc.

[7] Haryogo, A. 2013. Pengaruh Nilai Tukar dan Indeks Dow Jones Terhadap Composite Index di Bursa Efek Indonesia. FINESTA Vol. 1, No. 1: Hal. 1-6.

[8] Kurniawan, R. D dan Asandimitra, N. 2014. Analisis Perbandingan Kinerja Indeks Saham Syariah Dan Kinerja Indeks Saham Konvensional. Jurnal Ilmu Manajemen Vol. 2, No. 4: Hal. 1354-1366.

[9] Salim, J.F., Jamal, A., Seftarita, C. 2017. Pengaruh Faktor Dalam dan Luar Negeri Terhadap Indeks Harga Saham Gabungan (IHSG) di Indonesia. Jurnal Ekonomi dan Kebijakan Publik Indonesia Vol. 4, No. 1: Hal. 35-48.

[10] Sunariyah. 2006. Pengantar Pengetahuan Pasar Modal. Yogyakarta: UPP-AMP YKPN.
[11] Tirta, I. M. 2015. Panduan Penyusunan Modul dan Analisis Data Online Berbasis Web Interaktif Menggunakan $R$ dalam Rangka Melengkapi $K$ Statistika Virtual (Online, Interaktif, Terintegrasi). Jember: Universitas Jember.

[12] Tandelilin, E. 2001. Analisis Investasi dan Manajemen Portofolio. Yogyakarta: BPFE.

[13] Wahba, G. 1990. Spline Models for Observational Data. Pennsylvania: SIAM.

[14] Walpole, R. E., Myers, R.H., Myers, S.L., and Ye, K. 2012. Probability dan Statistics for Engineers and Scientists. Ninth Edition. London: Pearson Education LTD.

[15] Wu, H. and Zang, J. T., 2006. Nonparametric Regression Methods for Longitudinal Data Analysis. New Jersey: John Wiley and Sons. 